\title{
Perspektif Orangtua Terhadap Anak Autisme dan Peranannya Dalam Terapi (Studi Kasus PLA Provinsi Kepulauan Bangka Belitung)
}

\section{Zonalisa Fhatri}

IAIN Syaikh Abdurrahman Siddik Bangka Belitung, zonalisa_fhatri@yahoo.com

\begin{abstract}
ABSTRAK
Tujuan penelitian ini adalah untuk memperoleh gambaran mengenai penerimaan orangtua terhadap anaknya yang mengalami autisme serta perannya dalam terapi autis. Penelitian ini menggunakan pendekatan kualitatif. Karakteristik subjek penelitian meliputi orangtua yang memiliki anak yang didiagnosis mengalami autisme. Jumlah subjek dalam penelitian ini sebanyak 4 orang. Teknik pengumpulan data dengan wawancara sebagai metode utama dan observasi sebagai metode pendukung. Hasil wawancara menunjukkan bahwa secara keseluruhan keempat subjek dapat menerima sepenuhnya kondisi anak mereka yang didiagnosis autisme. Adanya penerimaan dipengaruhi faktor dukungan dari keluarga besar, diantaranya kemampuan finansial, latar belakang agama, usia, serta support para ahli dan masyarakat umum. Keempat subjek ini cukup berperan serta dalam penanganan anak mereka mulai dari memastikan diagnosis dokter/psikolog PLA, membina komunikasi dengan terapis PLA, memberikan informasi jujur saat berkonsultasi perkembangan anaknya, memperkaya pengetahuan, dan mendampingi anak saat melakukan terapi.

Kata Kunci: Penerimaan Orangtua, Anak Autisme, Peran Orangtua dalam Terapi
\end{abstract}

\begin{abstract}
The purpose of this study was to obtain a picture of the acceptance of parents of children with autism and their role in autism therapy. This research uses a qualitative approach. Characteristics of the study subjects included parents who had children diagnosed with autism. The number of subjects in this study were 4 people. Data collection techniques with interviews as the main method and observation as a supporting method. The interview results showed that overall all four subjects were able to fully accept the condition of their child who was diagnosed with autism. Acceptance is influenced by factors of support from extended families, including financial capacity, religious background, age, and support of experts and the general public. These four subjects are quite involved in handling their children ranging from ensuring the diagnosis of PLA doctors / psychologists, fostering communication with PLA therapists, providing honest information when consulting the development of their children, enriching knowledge, and assisting children when doing therapy.

Keywords: Parental Acceptance, Autism Children, The Role of Parents in Therapy
\end{abstract}

Article history:

Received: 28-11-2018

Revised: 10-1-2019

Accepted: 14-1-2019

Copyright (c) 2020 Fhatri 


\section{PENDAHULUAN}

Memiliki anak sehat jasmani dan rohani adalah harapan para orangtua. Harapan ini menyangkut pertumbuhan dan perkembangan yang paling optimal dari segi fisik, emosi, mental dan sosial setiap anak. Harapan tersebut tidak mudah terpenuhi jika anak mengalami gangguan perkembangan pervasif diantaranya Autisme. Autisme pada anak menyebabkan anak tidak mampu mengadakan interaksi sosial dan seolah hidup dalam dunianya sendiri. Autisme didefinisikan sebagai gangguan perkembangan dengan tiga gangguan perkembangan yaitu gangguan pada interaksi sosial, gangguan pada komunikasi dan keterbatasan minat serta kemampuan imajinasi. (Williams, 2007: 4).

Gejala autisme biasanya sudah tampak sebelum anak berusia 3 tahun, yaitu antara lain dengan tidak adanya kontak mata dan tidak menunjukkan respons terhadap lingkungan. Autisme bukanlah gejala penyakit tetapi berupa sindroma (kumpulan gejala) dimana terjadi penyimpangan perkembangan sosial, kemampuan

berbahasa dan kepedulian terhadap sekitar, sehingga anak autisme hidup dalam dunianya sendiri. Autisme tidak termasuk ke dalam golongan suatu penyakit tetapi suatu kumpulan gejala kelainan perilaku dan kemajuan perkembangan. Dengan kata lain, autisme adalah gangguan perkembangan otak pada anak yang berakibat tidak dapat berkomunikasi dan tidak dapat mengekspresikan perasaan dan keinginannya, sehingga perilaku hubungan dengan orang lain terganggu. (Sastra, 2011: 133).

Orangtua yang memiliki anak autisme segala sesuatunya pasti tampak berbeda dengan orangtua lainnya. Ketika periode awal kehidupan anaknya yang merupakan masa-masa yang tersulit dan paling membebani. Pada periode ini orangtua sering berhadapan dengan begitu banyak permasalahan. Tidak saja berasal dari anaknya, tetapi bercampur dengan masalah-masalah lainnya yang dapat membebani orangtua, termasuk permasalahan yang muncul dari reaksi masyarakat.

Reaksi pertama orangtua ketika anaknya dikatakan 
bermasalah adalah tidak percaya, shock, sedih, kecewa, merasa bersalah, marah dan menolak. Tidak mudah bagi orangtua anak autisme untuk mengalami fase ini, sebelum akhirnya sampai pada tahap penerimaan (acceptance). Ada masa orangtua merenung dan tidak mengetahui tindakan tepat apa yang harus diperbuat. Banyak orangtua akhirnya lebih memilih untuk menutupi keadaan anaknya dari teman, tetangga bahkan keluarga dekat sekalipun, kecuali pada dokter yang menangani anak tersebut. (Aguirre, 2014: 5).

Penerimaan ditandai dengan sikap positif, adanya penghargaan terhadap nilai-nilai individual, dan pengakuan terhadap tingkah lakunya. Penerimaan merupakan dasar bagi setiap individu untuk menerima kenyataan hidup baik itu pengalaman baik ataupun buruk.

Penerimaan orangtua sangat mempengaruhi perkembangan anak autisme dikemudian hari. Sikap orangtua yang tidak dapat menerima kenyataan akan berdampak negatif pada anak, karena secara sadar telah membuat anak merasa tidak dimengerti dan tidak diterima.
Sebagai implikasinya dapat menimbulkan penolakan juga dari anak (resentment) yang termanisfestasi dalam bentuk perilaku negatif yang tidak diinginkan. Bagaimanapun anak dengan gangguan autisme tetaplah seorang anak yang membutuhkan kasih sayang, perhatian dan cinta dari orangtua, saudara dan keluarganya. (Crain, 2014: 473).

Bentuk penerimaan orangtua dalam penanganan individu autisme adalah dengan memahami keadaan anak apa adanya, memahami kebiasaan-kebiasaan anak, menyadari apa yang sudah bisa dan belum bisa dilakukan anak, membentuk ikatan batin (bonding) yang kuat, dan mengupayakan alternatif penanganan sesuai dengan kebutuhan anak.

Gambaran tersebut diatas menjadi alasan bagi peneliti untuk melihat bagaimana penerimaan orangtua terhadap anak autisme serta peranannya dalam terapi autisme. Adapun, yang dimaksud orangtua dalam penelitian ini diasumsikan adalah ibu, dimana sebagian besar ibu adalah orang yang paling memahami dan berada paling dekat dengan anak, maka 
diharapkan peneliti mendapatkan data yang lebih banyak dan akurat mengenai penerimaan orangtua terhadap anak autisme serta peranannya dalam terapi autisme.

\section{METODE}

Penelitian ini menggunakan pendekatan kualitatif. Pendekatan kualitatif adalah penelitian yang lebih menekankan pada manfaat dan pengumpulan informasi dengan cara mendalami fenomena yang diteliti. Menurut Poerwandari penelitian kualitatif menghasilkan dan mengolah data yang sifatnya deskriptif, seperti transkripsi wawancara, catatan lapangan, gambar, foto, rekaman video, dan sebagainya.

Pendekatan kualitatif mencoba menerjemahkan pandangan dasar interpretif dan fenomenologis. Subjek pada penelitian ini adalah ibu dari anak autis yang berjumlah 4 orang, diantaranya: ibu HT, ibu AG, ibu LS, dan ibu KN. Metode yang digunakan untuk mengumpulkan data dalam penelitian ini adalah dengan melakukan wawancara dengan subjek dan significant other (terapis, ayah, pengasuh), serta melalui

observasi, baik observasi ke rumah subjek maupun tempat terapi dilaksaksanakan yaitu di PLA Provinsi Kepulauan Bangka Belitung.

\section{HASIL DAN PEMBAHASAN}

Dalam menerima kehadiran anak dengan gangguan autisme, beragam hal terjadi pada diri orangtua. Orangtua biasanya stres, kecewa, patah semangat, mencari pengobatan keman-mana, serba khawatir terhadap masa depan anaknya. Hal ini ditegaskan kembali oleh Williams dan Wright (2004) yang mengatakan bahwa keluarga akan melalui serangkaian emosi saat dikatakan anak mereka autis. Ini bervariasi pada setiap keluarga, dan setiap keluarga punya perjalanan emosionalnya sendiri.

Beberapa keluarga telah melalui proses diagnostik panjang dan beberapa harus menunggu lama waktu konsultasi. Beberapa menemukan prosesnya sangat cepat sehingga punya sedikit waktu untuk memikirkan akibatnya dari menata emosi mereka. Pada beberapa anak, diagnosis lebih mudah dibuat pada saat anak berusia dini dan pada beberapa, 
diagnosisnya sulit karena masalahnya lebih ringan. Semua ini dapat mempengaruhi bagaimana orangtua akan memikirkan langkah ke depan apa yang harus mereka lakukan.

Menurut Anjali Sastri dan Blaise Aguirre, semua orangtua memiliki respon dan perasaan berbeda saat anak mereka didagnosa menderita autisme. Beberapa reaksinya adalah sebagai berikut: a) Lega, jika orangtua memahami mengenai autisme dan mengetahui bagaimana mencari bantuan ahli. b) Rasa bersalah, adalah perasaan orangtua yang khawatir jika mereka melakukan hal yang salah selama kehamilan atau pengasuhannya. c) Kehilangan, jika mimpi dan cita-cita bagi anak mereka sebelum lahir dan saat mereka masih kecil tidak terpenuhi.

d) Ketakutan akan masa depan, disebabkan keluarga sangat takut akan masa depan anak-anak mereka dan harus mengubah harapan akan masa depan anaknya. e) Mencari informasi, keluarga ingin mengumpulkan informasi sebanyak mungkin dan mencari keluarga lain untuk berbagi pengalaman. Walaupun ada

beberapa keluarga yang mungkin menghindar dari informasi dan mencoba tidak memperdulikannya. (Aguirre, 2014: 69-76).

Dari uraian diatas terlihat bahwa orangtua sangat berperan dalam proses terapi. Adapun bentuk peran serta orangtua dalam terapi autisme sangat beragam, dari mulai mengantar ke tempat terapi, melakukan pendampingan secara intensif, melakukan pengecekan kepada terapis, mencari informasiinformasi baru untuk menambah wawasan sehingga dapat melakukan terapi dirumah, melakukan evaluasi secara periodik (harian, mingguan, bulanan), mengikuti perkumpulan orangtua anak penyandang autisme, serta selalu mengikuti perkembangan anak.

Terapi yang diberikan kepada setiap anak autisme memang akan lebih efektif apabila melibatkan peran serta orangtua secara aktif. Tujuannya agar setiap orangtua merasa memiliki andil atas kemajuan anaknya. 
A. Gambaran

Penerimaan

Orangtua

Autisme

\section{Kepulauan Bangka Belitung}

Gambaran

penerimaan

orangtua terhadap anak autisme dapat dilihat melalui bentuk-bentuk sikap penerimaan. Bentuk pertama, adalah memahami keadaan anak apa adanya (positif, negatif, kelebihan dan kekurangan). (David Smith, 2006: 341-342). Subjek pertama yaitu ibu inisial HT anaknya perempuan bernama inisial $\mathrm{JH}$ berusia 3 tahun. Mengemukakan bahwa kondisi anaknya adalah:

"sensitif terhadap bola bahkan mual/muntah jika didekatkan, suka berkeliling ruangan, suka bergumam, terkadang menangis bahkan menjerit. Tapi kelebihannya ananda JH lebih mudah dibujuk sama ibunya. Dan semenjak ikut terapi di PLA sekarang ada perkembangan, diantaranya tingkat sensitif ananda JH terhadap bola sudah berkurang terbukti dengan tidak muntah lagi jika didekatkan, terus tingkat mengamuknya sudah berkurang".

Selanjutnya subjek kedua yaitu ibu AG, anaknya laki-laki berusia 10 tahun dengan inisial NCD. Mengungkapkan bahwa kondisi anaknya NCD yaitu: "suka mengeluarkan cairan liur dari mulut, suka tersenyum sendiri dan terkadang tiba-tiba ngambek, badan dan gerakannya kaku, cara pandangnya miring, tidak respons jika dipanggil, tidak perduli dengan keadaan sekitar. kelebihannya anada NCD tidak mengganggu atau menyakiti orang di sekitarnya karena ia hanya sibuk dengan aktivitas menyendirinya".

Begitupun dengan subjek ketiga yaitu ibu LS anaknya lakilaki berusia 4 tahun dengan inisial RP. Mengatakan bahwa:

"keadaan anaknya suka mengamuk bahkan kalau ada kemauan yang tidak dituruti terkadang membentur kepala, kontak mata tidak fokus, lambat respons. Tapi semenjak sering terapi sekarang sudah banyak kemajuan, diantaranya sudah mudah dibujuk, mengamuknya berkurang, ekspresi salim, mencium, sayang dan toos, langsung respons".

Terakhir subjek keempat yaitu ibu KN anaknya laki-laki berusia 6 tahun dengan inisial AF. Menuturkan bahwa:

“anaknya baik di PLA maupun di rumah suka memutar benda, suka mengeluarkan air liur dari mulutnya 
(nginces), suka memanjat barangbarang tinggi, kalo dirumah suka memanjat kulkas, meja, bahkan pernah tertidur di atas lemari. Selain itu ananda AF suka kesandung karena sering berlari-lari tak terarah".

Bentuk kedua, adalah memahami kebiasaan-kebiasaan anak. (Aguirre, 2014: 241-246). Guna memahami kebiasaankebiasaan anaknya ibu HT mengatakan bahwa mempelajarinya dengan cara memperhatikan tingkah laku anaknya sehari-hari, dengan cara melatih dan menjalankan program yang diberikan pihak terapis PLA. Hanya saja terkadang waktu dan medianya terbatas.

Sedangkan subjek 2 melihat dari sifat-sifat, gerakan-gerakan, dan tangisan anak setiap hari sehingga mengerti dan memahami keinginan dan kemauan anaknya. Selanjutnya subjek 3, lebih konsen memperhatikan pola makan/diet anaknya. Ibu LS mengatakan bahwa:

"dari PLA anaknya dihimbau atau dilarang untuk makan seperti cokelat, terigu, minuman cepat saji, fermentasi, kentang dan buah yang berubah warna juga tidak boleh".

Subjek 4 yaitu ibu KN dan juga suaminya menuturkan bahwa, anak mereka AF dibiasakan di rumah main ayunan, menangkap/melempar bola. Selain itu, mereka mengurangi memberikan makanan manis, dan berhenti memberikan mie instan.

Bentuk ketiga, adalah menyadari apa yang bisa dan belum bisa dilakukan anak. (Aguirre, 2014: 246). Di dalam menyadari apa sudah dan belum bisa dilakukan oleh anaknya, keempat subjek ini banyak berdiskusi dengan dokter dan terapis yang menangani anak mereka. Hal ini sesuai dengan pendapat Danuatmaja (2003) bahwa kejujuran orangtua dalam menceritakan keseharian anak akan membantu dokter mengevaluasi kondisi anak yang dapat mempengaruhi kemajuan anak.

Pada subjek 1 banyak bertanya kepada terapis yang menangani di PLA. Subjek 2 membandingkan perkembangan anaknya dengan anak seusia 10 tahun. Sedangkan subjek 3 dan ke-4 dengan cara melihat dari tingkah laku anaknya 
dalam kesehariannya dengan cara itulah mereka dapat menyadari apa yang bisa dan belum bisa dilakukan oleh anaknya.

Bentuk keempat, adalah memahami penyebab perilaku buruk dan baik anak. (Crain, 2014: 471-472). Ketika anak cenderung sulit untuk diarahkan, subjek 1 dan 2 berusaha mencegah, bersikap tegas, dan tidak memanjakan anaknya. Akan tetapi bila sudah tidak bisa mereka akan menuruti kemauan anaknya. Subjek 3 dan 4 bisa memahami ketika anaknya menunjukkan perilaku yang buruk, menurut mereka hal itu dikarenakan anak sedang merasa bosan, sama halnya dengan subjek 3 dan 4, subjek 1 dan 2 bisa memahami ketika anaknya menunjukkan perilaku buruk hal itu dikarenakan anak sedang tidak mood.

Semua subjek ini memberikan rewad berupa ciuman, pelukan, dan tepuk tangan karena anak mereka dapat menunjukkan perilaku yang diinginkan. Hal ini sesuai dengan teori Rohner (2004) bahwa orangtua yang menerima biasanya ditunjukkan dengan adanya pelukan, ciuman, perhatian, kepedulian, dukungan serta memberikan kenyamanan pada anak sehingga anak akan merasa bahagia dan merasa aman jika didekat orangtuanya.

Bentuk keempat, adalah membentuk ikatan batin yang kuat yang akan diperlukan dalam kehidupan. Guna membentuk ikatan batin yang kuat yang dilakukan oleh ibu dengan anaknya, seperti bermain dengan anak, tidur bersama anak, mengajak anak jalan-jalan, ketika libur dan mengurus segala keperluan anak yang belum bisa dilakukan sendiri oleh anaknya. Ketika anak menjadi sulit untuk diarahkan dan mulai kembali ke dunianya, para ibu ini terkadang merasa kesal namun subjek berusaha untuk selalu bersikap santai. Orangtua harus bersikap santai dan hangat setiap kali bersama anak, sikap orangtua yang positif biasanya membuat anakanak lebih terbuka akan pengarahan dan lalu berkembang kearah yang lebih positif pula.

Bentuk yang kelima, adalah mengupayakan alternatif penanganan seuai dengan kebutuhan anak. Setiap sebulan 
sekali ketiga subjek rutin

denial (menolak menerima melakukan konsultasi pada dokter dengan membawa anak mereka sehingga dokter dapat langsung melihat keadaan anaknya sekarang. Peran dokter disini sangat penting dalam membantu memberikan keterampilan kepada orangtua untuk dapat menetapkan kebutuhan anak.

Guna menambah wawasan keempat ibu ini juga banyak membaca buku, majalah, dan koran yang mengulas seputas autisme. Mereka juga mengikuti seminarseminar autisme yang diadakan oleh pihak PLA Provinsi Kepulauan Bangka Belitung. Orangtua perlu memperkaya pengetahuannya mengenai autisme terutama pengetahuan mengenai terapi yang tepat dan sesuai dengan kebutuhan anak.

Selain bisa dilihat melalui bentuk-bentuk penerimaan terhadap anak autisme, untuk mendapatkan gambaran penerimaan orangtua, dapat pula dilihat melalui tahapan-tahapan orangtua dalam menerima kondisi anaknya yang mengalami gangguan. (David Smith, 2006: 339341). Tahap pertama adalah tahap kenyataan). Pada umumnya keempat subjek ini dapat menerima kenyataan atas kondisi anaknya yang didiagnosa menyandang autisme. Hanya saja mereka merasa terkejut, sedih, bingung, dan pasrah setelah mnegetahui kondisi anaknya yang sebenarnya.

Subjek 2 dan 3 pada saat itu sempat merasa malu pada keluarga dan lingkungan sekitar serta merasa kurang percaya diri memiliki anak yang menyandang autisme. Hal tersebut sesuai dengan pendapat David Smith yang mengatakan tidak mudah bagi orangtua manapun untuk dapat menerima apa yang sebenarnya terjadi. Kadang kala terselip perasaan malu pada diri orangtua untuk mengakui bahwa hal tersebut dapat terjadi di dalam keluarga mereka. Tahap kedua adalah tahap anger (marah). Reaksi marah bisa kepada diri sendiri atau kepada pasangan hidup. Bisa juga, muncul dalam bentuk menolak untuk mengasuh anak tersebut. Pernyataan yang sering muncul dalam hati dalam bentuk "tidak adil rasanya...", "mengapa kami yang mengalami ini?" atau "apa salah 
kami?” subjek kedua yaitu ibu AG kadang merasa jenuh, lelah, dan sedikit merasa kesal apabila anaknya NCD tidak menunjukkan perkembangan kemajuan yang berarti terlebih ketika anak sedang mempunyai kemauan yang sulit untuk dimengerti.

Tahap ketiga adalah tahap bargaining (menawar). Tahap ini adalah tahap di mana orangtua berusaha untuk menghibur diri dengan pernyataan seperti "mungkin kalau kami menunggu lebih lama lagi, keadaan akan membaik dengan sendirinya".

Keempat subjek ini dapat menerima dengan pasrah atas cobaan yang diberikan oleh Tuhan. Mereka menganggap ini semua adalah cobaan hidup yang mesti dilewati. Pada subjek 1 dan 3 setelah anaknya didiagnosa menyandang autisme, mereka langsung melakukan terapi-terapi sesuai dengan yang disarankan oleh dokter yang mendiagnosa. Sedangkan pada subjek 2 sempat selama setahun berhenti tanpa melakukan apa-apa, hanya berharap semua akan membaik dengan sendirinya.
Tahap keempat adalah tahap depression (depresi). Pada subjek 1 sempat timbul perasaan bersalah atas apa yang terjadi, subjek mengira bahwa hal tersebut mungkin berhubungan dengan dengan ada kesalahannya selama hamil. Subjek 2 dan 3 menjadi sulit tidur apabila memikirkan nasib, kesembuhan, dan perkembangan anak kedepannya. Depresi dapat juga menimbulkan rasa bersalah terutama pada pihak ibu, yang khawatir apakah keadaan anak mereka akibat dari kelalaian selama hamil atau akibat dosa dimasa lalu. Perasaan putus asa merupakan sebagian dari depresi yang muncul saat orangtua mulai membayangkan masa depan yang akan dihadapi sang anak.

Tahap yang terakhir tahap acceptance (pasrah dan menerima kenyataan). Semua subjek ini akhirnya mengerti dan menyadari anak penyandang autisme memang membutuhkan kasih sayang dan perhatian khusus. Pada awalnya mereka terkejut, sedih, dan bingung namun mereka pasrah menerimanya. Guna kesembuhan anak, mereka selalu mengikuti saran dokter dan mengikutsertakan 
anaknya dalam terapi-terapi yang mendukung kesembuhan anaknya seperti program terapi di PLA Provinsi. Orangtua sudah menyadari kenyataan baik secara emosional maupun intelektual. Sambil mengupayakan penyembuhan, mereka mengubah persepsi dan harapan atas anak, orangtua pada tahap ini cenderung mengharapkan yang terbaik sesuai dengan kemampuan dan kapasitas anaknya.

\section{B. Faktor-faktor} Memengaruhi Penerimaan Orangtua terhadap Anak

\section{Autisme}

Hasil penelitian juga memperlihatkan beberapa hal yang memengaruhi penerimaan orangtua terhadap anak autisme. Pertama adalah dukungan dari keluarga besar. Semua keluarga besar subjek 1 dan 2 sepenuhnya dapat menerima kondisi yang dialami oleh anaknya yang didiagnosa menyandang autisme. Se-dangkan respon dari keluarga subjek 3 ada yang menerima dan ada yang menolak kondisi anaknya. Semakin kuatnya dukungan keluarga besar, orangtua akan terhindar dari merasa sendirian, sehingga menjadi lebih kuat dalam menghadapi cobaan karena dapat bersandar pada keluarga besar mereka. (David Smith, 2006: 343-344).

$$
\text { Faktor kedua adalah }
$$

kemampuan keuangan keluarga. Keuangan keluarga yang memadai, dapat memberikan kesempatan yang lebih baik bagi orangtua untuk dapat memberikan penyembuhan bagi anak mereka. Dengan kemampuan finansial yang lebih baik, makin besar pula kemungkinan orangtua untuk dapat memberikan beberapa terapi sekaligus, sehingga proses penyembuhan juga akan semakin cepat.

Subjek 1 dan 2 yang merupakan ibu HT dan AG, memiliki tingkat sosial ekonomi menengah ke atas, sedangkan subjek 3 ibu LS memiliki ekonomi menengah. Pada subjek 1 dan 2 tidak sulit baginya untuk memberikan kesempatan beberapa terapi sekaligus.

Faktor ketiga adalah latarbelakang agama. Pertama kali mengetahui bahwa anaknya didiagnosa menyandang autisme, keempat ibu tersebut merasa 
terkejut dan sedih. Subjek 2 dan 3 bersikap pasrah dan ikhlas dalam menerima takdir sebagai pemberian dari Tuhan dikarenakan anaknya dari bayi sudah mengalami kejangkejang sebelum didiagnosa menyandang autisme. Perasaan bersalah sempat muncul dalam benak subjek 1 dan 3 , namun mereka segera menyadari bahwa semua itu harus dilewati. Bahkan subjek 3 pada awalnya merasa bahwa semua ini akibat dari ketidakadilan Tuhan kepadanya, sampai akhirnya ia dapat menerima cobaan itu dengan lapang dada. Begitupun dengan subjek keempat yaitu ibu KN, baginya keadaan AF tidak membuat ia dan keluarganya merasa rugi justru semenjak kehadiran $\mathrm{AF}$ di rumah mereka, keluarga ini merasa lebih berkah dan banyak rejeki.

Kepercayaan yang kuat kepada Yang Maha Kuasa membuat orangtua yakin bahwa mereka diberikan cobaan sesuai dengan porsi yang mampu mereka hadapi. Dengan keyakinan tersbut, mereka mengupayakan yang terbaik untuk anak mereka, dan percaya bahwa suatu saat, anak tersebut akan mengalami kemajuan.
Faktor keempat adalah sikap para ahli yang mendiagnosa anaknya. Psikolog yang mendiagnosa subjek 1 dan 2 memberikan semangat kepada mereka untuk terus menjalani terapi demi kesembuhan anak mereka. Sedangkan subjek 3 sering berkonsultasi ke dokter untuk menceritakan tiap-tiap perubahan yang terjadi pada anaknya sehingga dokter dapat memberikan masukan serta dukungan pada subjek LS tersebut. Dokter ahli yang simpatik, akan membuat orangtua merasa dimengerti dan dihargai. Apalagi jika dokter memberikan dukungan dan pengarahan kepada orangtua (atas apa yang sebaiknya mereka lakukan selanjutnya). Sikap dokter ahli yang berempati, membuat orangtua merasa memiliki harapan, bahwa mereka tidak sendirian dalam menghadapi rintangan ini.

Faktor keempat adalah sikap para ahli yang mendiagnosa anaknya. (Aguirre, 2014: 107-108). Psikolog PLA yang mendiagnosa subjek 1 dan 2 memberikan semangat kepada mereka untuk terus menjalani terapi demi kesembuhan anak mereka. Sedangkan subjek 3 sering 
berkonsultasi ke dokter untuk menceritakan tiap-tiap perubahan yang terjadi pada anaknya sehingga dokter dapat memberikan masukan serta dukungan pada subjek. Dokter ahli yang simpatik, akan membuat orangtua merasa dimengerti dan dihargai. Apalagi jika dokter memberikan dukungan dan pengarahan kepada orangtua (atas apa yang sebaiknya mereka lakukan selanjutnya).

Faktor ketujuh adalah sikap masyarakat umum. (David Smith, 2006: 350) Lingkungan tempat tinggal subjek 1 dan 2 semua sangat mendukung dan dapat menerima keadaan anaknya. Namun pada awalnya subjek 2 sempat merasa malu untuk terbuka pada lingkungan, akan tetapi pada akhirnya lingkungan lambat laun dapat menerimanya. Pada masyarakat yang sudah lebih "menerima", mereka akan berusaha memberikan dukungan secara tidak berlebihan (pada saat berhadapan dengan anak-anak dengan kebutuhan khusus). Menanyakan secara halus apakah orangtua perlu bantuan, memberikan senyuman kepada sang anak, memperlakukan orangtua seperti layaknya orangtua lain (dengan anak yang normal), merupakan hal-hal sederhana yang sebetulnya sangat membantu menghilangkan stres pada keluarga dari anak dengan kebutuhan khusus.

Sedangkan lingkungan subjek 3 ada yang menerima dan ada juga yang menolak kehadiran anaknya. Hal tersebut membut subjek merasa bingung dan menambah berat beban hidupnya. Faktor kedelapan adalah usia dari masingmasing orangtua. Ibu HT berusia 34 tahun, subjek dapat menentukan jalan keluar yang terbaik untuk kesembuhan anaknya. Ibu AG berusia 36 tahun, mereka cukup matang dan dapat bersikap dewasa dalam memahami kondisi anak. Sedangkan LS berusia 29 tahun, ia dapat menerima diagnosa dengan tagak cemas, dan terakhir ibu KN berusia 43 tahun sudah bisa menerima informasi diagnosa dengan sabar dan tenang. Usia yang matang dan dewasa pada pasangan suami isteri, memperbesar kemungkinan orangtua untuk menerima diagnosa dengan relatif lebih tenang. Dengan kedewasaan yang mereka miliki, pikiran serta tenaga mereka 
difokuskan pada mencari jalan keluar yang terbaik.

Faktor yang terakhir adalah sarana penunjang. (David Smith, 2006: 349). Semakin banyaknya sarana penunjang, semakin mudah pula orangtua melatih anak mereka di rumah. Ibu HT mengemukakan bahwa:

"fasilitas di rumah tidak memadai dan selengkap di PLA, jadi cara kami melatih JH seadanya saja dengan media sederhana yang ada dan menyesuaikan, selain itu waktu juga terkadang tidak mendukung".

Sedangkan penuturan oleh ibu LS bahwa:

"anak saya $R P$ selama di rumah sering kami biarkan ia memanjat, mengajak jalan di alam bebas supaya RP lebih luwes dan nyaman belajar dan ketika $R P$ di dalam rumah sering saya ajarkan meronce, tos jari, melempar/tangkap bola, naik-turun tangga karena kebetulan rumah kami 2 tingkat, terus $R P$ juga saya latih menyobek/meremas kertas atau tissue". Jadi ibu LS tidak mengandalkan fasilitas mewah, ia lebih memanfaatkan alam bebasdan media sederhana yang ada, untuk melatih anaknya belajar".

Adapun ibu KN dan suaminya, mengatakan bahwa:

"ada ruangan tamu khusus $A F$ beraktifitas semaunya, karena sengaja dikosongkan, peralatan rumah seperti meja, kursi, lemari disingkirkan ke pinggir, biar $A F$ bebas bergerak di mana saja dan tidak membuatnya memanjat. Cara orangtua AF di rumah adalah dengan penataan peralatan yang memberikan peluang $A F$ untuk luwes bergerak sehingga barangbarang yang bersifat menghalangi atau membahayakan mereka amankan dulu".

\section{Peranan Orangtua dalam Terapi Anak Autisme}

Hasil wawancara ini juga mengungkap beberapa peranan orangtua dalam terapi anak autisme. Pertama adalah memastikan diagnostik. (Aguirre, 2014: 101). Setelah menyadari kelainan yang dialami oleh anaknya, ibu HT langsung mencari dokter anak untuk memastikan diagnostik. Ia juga bertanya kepada kerabat, tetangga, dan temanteman mengenai keadaan anaknya, bahkan internet sampai akhirnya ia membawa anaknya ke Psikolog PLA dan didiagnosa menyandang autisme lalu langsung diatur jadwal terapi.

Subjek 2, ibu AG setelah menyadari kelainan yang dialami oleh anaknya langsung memeriksakan anaknya ke dokter saraf dan juga obat alternatif kampung ala Tionghoa (shinshang), 
pada akhirnya ibu AG dan suami menemukan informasi mengenai PLA (pusat layanan autis) dari informasi teman. Selanjutnya subjek 3 yaitu yaitu ibu LS. Beliau mengatakan bahwa:

"ketika kami sadar anak kami perkembangan komunikasi, dan tingkah lakunya agak berbeda dengan anak tetangga dan anakanak biasanya, kami mulai risau dan mencoba bertanya pada bidan dekat rumah, dianjurkan untuk konsultasi ke dokter anak, kata dokternya anak kami RP tergolong autis, kami bingung apa itu autis karena masih awam bagi kami. Setelah disarankan oleh dokter untuk $R P$ ikut terapi, saya dan suami mencari tahu tempat-tempat terapi, akhirnya lewat informasi dari keluarga bahwa ada pusat terapi anak autis di Pangkalpinang-air itam, dan akhirnya kami datang ke PLA ini dan Alhamdulillah kami dilayani dengan baik".

Terakhir subjek ke-4 ibu KN, mengemukakan bahwa:

"karena sadar dengan keadaan si $A F$ berbeda dengan anak umumnya, makanya $A F$ sering dibawa kontrol ke dokter saraf dan dokter umum juga, kami terus berusaha karena sangat menyayangi AF. Waktu itu pas AF demam kami berobat di rumah sakit umum Pangkalpinang, kebetulan dokternya memberikan kami brosur PLA yang saat itu baru buka. Terus kami mencari PLA tersebut dan akhirnya ketemu, sampai saat ini $A F$ masih rutin ikut terapi di PLA dan Alhamdulillh sudah banyak perkembangan dibanding dulu, para terapis pun sangat baik dan ramah, kami sangat berterima kasih".

Sesungguhnya peran orangtua bagi anak penyandang autis sangat penting. Banyak hal yang bisa dan harus dilakukan orangtua anak autis yaitu memastikan diagnostik, sekaligus mengetahui ada tidaknya gangguan lain pada anak untuk ikut diobati, Orangtua harus dapat memilih dokter yang kompeten seperti dokter anak yang menangani autisme, dokter saraf anak. Selain itu orangtua harus berkata jujur saat konsultasi, sehingga membantu para terapis dalam mengevaluasi kondisi anak yang bisa mempengaruhi kemajuan anaknya.

\section{KESIMPULAN}

Berdasarkan bentuk-bentuk penerimaan orangtua secara keseluruhan keempat subjek dapat menerima sepenuhnya kondisi anak mereka yang didiagnosis autisme. Beberapa tahap yang dilalui oleh para ibu ini dalam proses mencapai penerimaan terhadap anaknya yang didiagnosa autisme, yaitu tahap 
denial, Anger, bargaining, depression dan acceptance. Namun keempat ibu ini melalui tahapan yang berbeda-beda karena kondisi anak mereka juga berbeda-beda.

Penerimaan orangtua terhadap anak autisme dipengaruhi oleh dukungan dari keluarga besar, kemampuan finansial keluarga, latar belakang agama, usia serta dukungan para ahli dan masyarakat umum. keempat subjek ini sudah cukup berperan serta dalam penanganan anak mereka, mulai dari memastikan diagnosis dokter/psikolog PLA, membina komunikasi dengan terapis, memberikan informasi jujur saat berkonsultasi perkembangan anaknya, memperkaya pengetahuan, serta mendampingi anak saat melakukan terapi.

\section{DAFTAR PUSTAKA}

Anjali Sastry dan Blaise Aguirre, 2014, Parenting Anak dengan Autisme, Yogyakarta: Pustaka Belajar.

Crain, William, 2014, Teori Perkembangan Konsep dan Aplikasi, Edisi Ketiga, Yogyakarta: Pustaka Belajar.
David Smith, 2006, Inklusi: Sekolah Ramah untuk Semua, Bandung: Nuansa.

Delphie, Bandie, 2009, Pendidikan Anak Autistik, Yogyakarta: PT Intan Sejati Klaten.

Firdani, Lara, 2009, Inspiring Education PAUD, Jakarta: Kompas Gramedia.

Gusdi Sastra, 2011, Neurolinguistik Suatu Pengantar, Bandung: CV. Alfabeta.

Maulana, Mirza, 2007, Anak Autis: Mendidik Anak Autis dan Gangguan Mental Lain Menuju Anak Cerdas dan Sehat, Yogyakarta: Ar-Ruzz Media.

Morrison, George S, 2012, Dasardasar Pendidikan Anak Usia Dini, Edisi Kelima, terj. Suci Romadhona dan Apri Widiastuti, Jakarta: PT Indeks.

Mudjito, et al., 2014, Deteksi Dini, Diagnosa Gangguan Spectrum Autisme dan Penanganan dalam Keluarga, Jakarta: Kementerian Pendidikan dan Kebudayaan.

Smith, David J, 2006, Inklusi Sekolah Ramah untuk Semua, terj. Denis dn Ny. Enrica, Bandung: Nuansa.

Thompson, Jenny, 2014, Memahami Anak Berkebutuhan Khusus, terj. Eka Widayati, Jakarta: Erlangga.

Wright B dan C. Williams, 2007, How To Live With Autism And Aspeger Syndrome, Jakarta: Dian Rakyat. 